\title{
The Parliamentary Dimension of Security Sector Reform
}

\author{
Willem van Eekelen*
}

\begin{abstract}
With the end of the Cold War greater responsibilities have fallen on parliaments worldwide, including in European countries. In the new democracies of Eastern Europe, parliaments needed to seize the opportunity to install effective systems of control of the security sector, including the defence sector which is the subject of this article. But reform of parliamentary oversight is also needed in Western Europe because of the new and more complex security environment. A list of parliamentary best practice is presented, based on the principles of accountability, oversight and transparency, for policy formulation, legislation, expenditures management and procurement decisions. Measured against this yardstick, parliamentary oversight still falls short in many NATO member countries.
\end{abstract}

Keywords: Armed forces, security sector, parliamentary oversight

\section{Drivers of security sector reform}

$\mathrm{S}$ ecurity sector reform became a current concept only after the end of the Cold War when the new democracies of Central and Eastern Europe sought membership in Western organisations. With the ending of the division of Europe, defence in the limited sense of the protection of territorial integrity and national independence lost its overriding priority. The NATO strategic concept talked about new risks and challenges and the need to focus on maintaining and restoring stability. Planning shifted from a threat-driven to a capability-driven strategy. Understandably so, because the new risks were largely non-military: illicit immigration, drugs and organised crime. The West resumed the threat vocabulary only after the attacks on the twin towers in New York and the Pentagon on 11 September 2001. But again the threat of catastrophic terrorism could not be combated with military means only, and the threat of proliferation of weapons of mass destruction has not yet found a comprehensive strategy.

Obviously, parliamentarians dealing with politico-military affairs have followed these questions closely, but to them the most striking change occurred in the blurring of the dividing line between external and internal security. This awareness grew during the agonising break-up of Yugoslavia with its barbarous flares of intra-state ethnic and religious violence. It took a new turn after 9/11 demonstrated that the next attack might be close to home.

Security Sector Reform (SSR) in Europe initially had a patronising aspect in concentrating on the countries aspiring to NATO membership. In fact, security sector reform should have equally been applied in many old member states, for their defence establishments were just as much in need of reform. As we shall see later in this article, democratic control was and is far from perfect and showed enormous variations. In the West, however, the emphasis was on capabilities, first in general terms to overcome the slack of the peace dividend, and later, under the call for transformation,

\footnotetext{
* Dr. W. F. van Eekelen was Minister of Defence in the Netherlands, Secretary General of the WEU and a senator in the Dutch parliament. Currently he is chairman of the European Movement in the Netherlands, a member of the SIPRI governing board and of the DCAF international advisory board.
}

towards network centric warfare. However, the increasing demands on political decision-makers on the structure and the use of armed forces now require a general revisiting of the way in which security sectors are organized.

In Central Eastern Europe reform progressed in phases, beginning with the setting of democratic norms and institution-building. A crucial element of reform was to make sure that the security sector would obtain legitimacy and no longer dominate society. During this phase the armed forces not only had to adapt to new tasks, but also to cope with unprecedented downsizing, often cutting as much as two-thirds of previous establishments. No wonder resistance to change was widespread and could only be overcome by the perspective of NATO membership. The next phase concerned more advanced reforms, a second generation of SSR. In the political field this implied practical implementation of the new legislation and democratic norms. For the military it meant multi-annual planning, participation in multinational peace support operations with the ensuing need for interoperability of procedures and equipment and a continuing struggle to maintain an acceptable ratio in the budget between investment and the cost of operations and maintenance. ${ }^{1}$

Traditionally, parliamentarians had few incentives to get deeply involved in security matters, except in the few cases in which jobs were at stake in deciding military contracts. It was not a subject to gain many votes by. Today, security policy moves to centre stage and involves highly political questions such as: What peace support operations should we get involved in? How do we obtain legitimacy for such actions, both nationally and internationally? What combination of armed forces is most suitable to these tasks? Are we prepared to accept scenario-planning with some degree of commitment concerning our contributions to multinational units? How much command and control should be relinquished to the commanders of these units? And are we prepared to accept a form of international financing for such operations? In the field of development co-operation, increasingly the

\footnotetext{
1 See e.g. Wilhelm N. Germann and Andrzej Karkoszka (eds.), Security Sector Reform in Central and Eastern Europe. Difficult Paths Towards Success, Baden-Baden 2005
} 
link is being recognised between security and development: without security on the ground, development efforts are not sustainable and make little sense. Finally, the fight against terrorism has highlighted the need for more co-operation between the many civilian agencies involved. In the US this has led to the creation of a Department for Homeland Defence integrating dozens of governmental organisations. Its effectiveness still has to be assessed. Within the EU, 9/11 has led to an acceleration of a spectrum of activities ranging from common arrest warrants, joint investigation teams, added competences for Europol, co-operation among public prosecutors to a list of forbidden organisations which should not receive financial support, and measures against moneylaundering. The new EU Constitution contains an article of solidarity in assisting countries which have become the victim of a terrorist attack and request help. Even if the Constitution does not enter into force this provision is likely to be maintained.

At the parliamentary level all these activities merit scrutiny, with particular attention to their mutual coherence, but also to the balance between security and individual freedom of the citizen. If we allow our democratic societies to be disrupted by the threat of terrorism, the terrorists will already have achieved their objective.

\section{The essence of parliamentary control}

In a democracy the government should reveal, explain and justify, both in terms of a detailed budget and its legislative programme. The parliament, through its committees, should test the assumptions, examine alternatives and take responsibility for the allocation of funds to the various government departments. In the field of defence these tasks are difficult because they require considerable expertise, sometimes involving confidential information (although the need for secrecy is often exaggerated by the military), and an integrated ministry of defence which is sensitive to democratic requirements. Conversely, politicians should refrain from micro-management as soon as competences and mandates have been clearly established.

Within Europe the need for a civilian minister of defence has been widely recognised, but often the co-operation between military and civilian personnel leaves much to be desired, and the relationship between the minister and the Chief of Defence Staff is not sufficiently defined. Certain functions within the ministry should be entrusted to civilians, like general policy planning and relations with parliament, while in the fields of information, personnel and procurement a civilian-military mix is important.

The challenge of parliamentary scrutiny is to devise a method through which the constitutional role of the legislature can be exercised in a purposeful and professional manner. If a rigorous method is not formalised, parliamentary control is in danger of becoming political rhetoric leaving too many opportunities for the bureaucracy and the military to go their own way.
A logical but somewhat theoretical sequence is to start with the formulation of a national strategy followed by a security strategy, which becomes the basis for a military doctrine and force structure. That is the way the US conducts its Quadrennial Defence Review, which is due again in February 2006. Most other countries combine these stages in a comprehensive White Paper or similar policy document which is put before parliament and forms the basis for defence policy for the medium term. For parliamentarians it is policy which matters most.

In any case a policy making and review cycle has to be based on an assessment of the entire range of security problems facing a country and identification of priorities among them. Parliamentarians will need to be able to judge alternative options and methods of implementation. An important part of their work is to ascertain whether the decisions proposed by the government are coherent and consistent and affordable in terms of the financial means available. The next step is monitoring in terms of costs and benefits and evaluation of the outcome. The cycle is closed by policy reassessment, adjustment or termination. A decision to stop or alter a policy means initiating a new policy, which starts a new cycle.

The growth of the security sector has serious implications for parliamentary scrutiny. It no longer involves only the military. In fact, democratic control of a military which primarily functions abroad has less priority for the ordinary citizen than the behaviour of the forces of law and order at home. Corruption of the police or violations of human rights gnaw at the roots of democracy. Concern with the military is of a different order: the armed forces should not become a state within the state, but accept the primacy of politics. If they do, their professional advice will weigh heavily in the decision making process and the politicians will bear full responsibility for neglecting it.

The security sector consists of all forces and services authorised to use force: military, police, paramilitary, intelligence and secret services, coast- and border guards, civil defence and national guards. Today, it also includes all government bodies charged with management and oversight, including the legislature and its select committees; justice and law enforcement institutions; and non-statutory security forces like private security companies or political party militias. ${ }^{2}$

It is no easy task to take a comprehensive look at the regulation of all these institutions and their behaviour in practice. The security sector has become part of the wider societal and political context and cannot function effectively if the administrative and legal framework is fundamentally weak or corrupt.

The following observations which are based on the author's personal experience and a detailed examination of parliamentary oversight in NATO member countries focus on the defence sector. This is a matter of expediency, parliamentary control is also in need of rejuvenation in other parts of the security sector, of which there is not enough space to go into detail here.

2 Dylan Hendrickson and Andrzej Karkoszka, »The challenges of security sector reform«, SIPRI Yearbook 2002, London 2002, p. 179; see also the contributions by Heiner Hänggi and Wolf Poulet in this volume. 


\section{Parliamentary practice}

Conceptually, parliament is sovereign and scrutinises and authorises the defence budget. It enacts legislation and holds the executive accountable for the development, implementation and review of the security and defence policy. It also is involved in declaring and lifting a state of emergency or war. Parliamentary practice, however, is far from uniform.

Parliaments of NATO countries exert varying degrees of influence and do so in different ways. All have Standing Committees on Foreign Affairs and Defence, many also on European Affairs and Intelligence. Germany probably has the closest scrutiny of the defence budget. France works with a rapporteur whose findings are subject to a general debate. The Netherlands legislative process contains several rounds of written comments and questions from all parties to which the government responds extensively before an oral debate can take place.

The distinction is between those parliaments which have formal powers of consultation and decision, and those whose influence is indirect through their ability to hold the executive accountable albeit "after the event «. At one end of the spectrum is the US Congress which, under the separation of powers, holds the Department of Defence firmly accountable, often in excruciating detail. Both Senate and House of Representatives and their members have unparalleled resources in terms of staff and supporting resources.

At the other end of the spectrum is the British Parliament, whose direct oversight consists of voting the defence budget as a global figure once a year, plus various debates. The Government does not have to obtain parliamentary approval for specific expenditure decisions. Parliament exerts little influence over the development of the British defence budget, which rests firmly in the hands of the executive. Again, this relationship is a function of British history and the development of a strong executive depending on a highlyprofessional and relatively insular civil service.

The function of the British Parliament and its select Committee on Defence has to be seen in a different context. It plays a major role in informing public opinion and making defence more transparent, through focused hearings and reports. Likewise, the national Audit Office which reports to parliament keeps the government on its toes by in-depth assessments of various programmes looking specifically to see that expenditure has been used effectively.

Most other parliaments exert considerably more direct influence than the British but fall short of the Congressional model. The German Bundestag, the Netherlands and Danish parliaments offer more appropriate models as they enjoy formal consultative powers on issues such as equipment purchases and force deployments.

Within this overall distinction of direct and indirect influence, parliamentary activity can therefore be grouped into three broad areas: accountability, oversight and transparency.

\subsection{Accountability}

All parliaments hold their governments accountable through the annual voting of the necessary funds, whether this is the end of a long process of examination or merely formal endorsement. Whatever the model, the "power of the purse requires every government to explain and justify its expenditure demands. Accountability is also achieved through hearings or the establishment of special committees to look into specific issues. Examples of the latter were the investigation by the Canadian parliament into the conduct of Canadian soldiers in Somalia, and the enquiry by the Belgian parliament into the events that led to the deaths of Belgian peacekeepers in Rwanda.

\subsection{Oversight}

The crucial issue is the degree to which oversight translates into real influence over the decisions of the executive. Parliamentary authorisation is an important instrument of influence. In many countries parliamentary authorisation is required for the purchase of major weapon systems, which in effect equates with participation in the decision.

Several Alliance parliaments have the constitutional requirement to be informed on the deployment of forces abroad, a few have the right to participate in the decision through formal authorisation. The new missions will increase the demand for parliaments to be kept informed on a more time urgent basis and to be consulted on the terms of deployment. ${ }^{3}$ This will further test the balance between democracy and military efficiency. Similarly, the use of force in conditions short of war, for example, during the air campaign against Yugoslavia, or the recent operation in Afghanistan reflect this need. However, in all Alliance countries, irrespective of the formal powers of consultation, parliamentary support is a precondition for involvement in such contingencies.

Most parliaments also have the responsibility to ratify treaties, including obviously NATO and EU enlargement. The real question is how far parliaments should intrude into the making of defence policy and the running of the armed forces, for example: should they be informed or consulted on operational matters; or on development of strategy and doctrine; or on procurement decisions?

Again, the question arises of the dividing line between things military and political. As Simon Lunn concluded, common sense suggests that there are many areas where parliament should not be directly involved in telling the military how to do their business. ${ }^{4}$ On the other hand, parliament should be

3 For a comparative review of the powers of parliaments in Peace Support Operations, see Hans Born and Marlene Urscheler, »Democratic Accountability and Parliamentary Oversight of Multinational Peace Support Operations: Powers and Practices of Parliaments in 17 Countries«, paper presented at »The Fourth PCAF Workshop Strengthening Parliamentary Oversight of International Military Co-operation / Institutions in Euro-Atlantic Area«, Brussels, 12-14 July, 2002, available at http://www.dcaf.ch/pcaf/ -virtuallibrary/-publications/-CF22.HANS.BORNMARLENE.URSCHELER.pdf.

4 See Simon Lunn, »The Democratic Control of Armed Forces in Principle and Practice", in Hans Born, Philipp H. Fluri and Simon Lunn (eds.), Oversight and Guidance: The Relevance of Parliamentary Oversight for the Security Sector and its Reform. A Collection of Articles on Foundational Aspects of Parliamentary Oversight of the Security Sector, Geneva/Brussels 2003, available at http://www.dcaf.ch/publications/Publications\%20 New/DCAF_Documents/DCAF.DOC4.pdf. 
kept fully informed through regular and timely consultation; and all areas should be open to parliamentary oversight and scrutiny, the executive should have the flexibility to exercise power responsibly but must always be mindful that parliament is watching.

\subsection{Transparency}

Parliamentary debates and reports help make defence more transparent and increase public awareness of defence. They play an important role in building the public consensus essential for defence. Parliamentary work in defence should form an important part of a general security environment and the creation of a defence community in which security is freely and openly discussed and ceases to be the property and prerogative of a few.

Discussion of the role of parliaments would not be complete without a mention of their role in the broader context of civil-military relations. Parliamentarians form a natural link between the armed forces and the society. Many parliamentarians have particular connections through having military facilities or defence industries in their constituencies or because they themselves have a military background. Defence committees are frequently active in looking after the welfare and rights of soldiers.

What then are the obstacles to effective parliamentary involvement? Whatever the model and degree of involvement, parliamentary effectiveness depends on parliamentarians being well informed and knowledgeable. However, again the unique characteristics of defence make the acquisition of the required competence problematic. As a subject, defence has always lent itself to both secrecy (in the sense that the provision of adequate information has often been limited for reasons of national security) and exclusivity. With the passing of the Cold War, this factor has become less inhibiting but confidentiality still tends to limit the flow of essential information to a qualified few. Frequently, the executive is unwilling to make available the required information, on the grounds of its sensitive nature. Membership of international organisations such as NATO is often used as a reason to withhold information due to the rules of the organisation, which inevitably always works transparency down to the level of the most security conscious. Parliaments deal with the issue of confidentiality in different ways. Most work on a $»$ need to know « basis, albeit that it is the executive that decides »the need «. Some hold closed hearings to satisfy the requirement.

\section{Specific tasks for Defence Committees}

A good part of parliamentary work on defence issues needs to be done in the defence committee, whose tasks shall here be spelled out in some more detail. The listing is based on an examination of practice in NATO member countries and development of a »best practice $\ll$ model. ${ }^{5}$

5 See Willem van Eekelen, »Democratic Control of Armed Forces: the national and international dimension«, DCAF Occasional Paper No 2, Geneva 2002.
On security policy:

- to examine and report on any major policy initiative announced by the ministry of defence;

- to report annually on the ministry of defence's performance against the objectives of the national military/security strategy;

- to periodically examine the defence minister on his discharge of policy responsibilities;

- to keep under scrutiny the ministry of defence's compliance with freedom of information legislation, and the quality of its provision of information to parliament by whatever means;

- to conduct inquiries and report to the parliament on any issues raising special concern (as can happen in Belgium, Canada, Germany, Hungary, Italy, Norway, and others, though it is not in the authority of the committee in countries such as Poland and Turkey);

- to examine petitions and complaints from military personnel and civilians concerning the security sector.

On legislation:

- to consider, and report on, any draft legislation proposed by the government and referred to it by the parliament;

- parliament should decide the size, composition, structure and the medium and longer term development of the armed forces. It should also adopt (or take note of) defence White Papers or similar documents, laws on the legal status of military personnel (and, where applicable, the rights of conscientious objectors), recruitment, promotion and career perspectives;

- to consider international or regional treaties and arrangements falling within the area of responsibility of the ministry of defence, and to draw the attention of the parliament to those which raise particular questions of policy requiring debate or other consideration: ratification or adhesion, corresponding policy and legislation, budgetary appropriations;

- if appropriate, to initiate new legislation by asking the minister to propose a new law or by drafting a law itself (as is the case with the committees on defence or national security of Belgium, Canada, Hungary, Italy, Norway, Poland, Turkey and others).

On expenditures:

- to examine, and report on, the main estimates and annual expenditures of the ministry of defence;

- to consider each supplementary estimate presented by the ministry of defence and to report to the parliament whenever this requires further consideration;

- to report periodically on the impact of efficiency savings on the running cost of the ministry of defence;

- if necessary, to order the competent authorities to carry out an audit.

On management and administration:

- to consider the reports and accounts of each branch of the armed forces and to report periodically on whether any matters of particular concern are raised;

- to consider and, if appropriate, to take evidence and report on each major appointment made by the relevant execu- 
tive authority (leading military commanders, top civil servants);

- to consider the internal organisation of the defence sector, eventually through external bodies relating to the parliament (e.g. ombudsman), and to draw the attention of the parliament to possible malfunctioning.

On equipment: 6

- In this process the first communication should be sent to parliament when the operational requirement has been determined in general terms: the type of equipment and a general indication of the numbers needed. In many cases the new equipment will replace older and outdated equipment. New technologies might reduce the numbers required, but will also affect the cost of the project. Some indication will have to be given of the volume of funding reserved for the procurement. Parliamentarians are likely to focus on the share of the overall budget to be absorbed by the new plans and pose questions concerning their compatibility with other priority needs.

- In approving the requirement the committee takes note of the documents presented. The next phase concerns preparatory studies on a number of subjects. The operational requirements have to be translated into technical specifications. The market has to be explored and an exhaustive list of all possible suppliers drawn up. Or, if it appears that nothing much is yet available in the near future, plans have to be drawn up for a development phase in cooperation with industry and, where possible, with other interested countries. In both cases a procurement strategy has to be established, as well as a timetable for production and delivery to the armed forces.

- The third step is a thorough study of the information provided by interested suppliers. Are they able to fulfil all specifications or do they suggest alternative ways of meeting the requirements? Is the equipment in use by other forces and what are their experiences regarding performance? What are the possibilities for co-production and compensation? This study should lead to a shortlist of alternative products. Depending on the parliamentary practice of the country concerned, this information should be made public and subjected to discussion in the competent parliamentary committee.

- The fourth phase concerns preparations for the acquisition on the basis of negotiated offers, possibly complemented by field trials. The armaments directorate will apply a range of criteria in arriving at its final judgment. Assuming that several alternatives meet the military requirements, other factors enter the fray. What are the life-cycle costs; are there gradations in military effectiveness and the safety of the personnel?

- Concurrently, the ministry of economic affairs, or another agency responsible for the involvement of domestic industry in military production, will negotiate co-production and, when necessary, complementary compensation outside the project concerned. Over time parliaments have

6 A model sequence of reporting on procurement in order to obtain parliamentary approval is taken from practice in the Netherlands. become more demanding and usually require one hundred percent compensation for every defence dollar or euro spent abroad. As foreign suppliers tend to paint too rosy a picture of their compensation activities, parliaments are pressing for penalty clauses if the targets are not met. Putting them into contracts, however, is no easy matter as usually the time allowed for effecting compensation is prolonged and might cover some ten years. In the meantime, some plans will have lost their feasibility or other possibilities have opened up. In any case, no contract will be signed until it has become clear that the domestic industry will be adequately involved in its implementation.

- This final phase is subject to intense lobbying, involving media, think tanks and parliamentarians. Decision makers are invited to visit factories or attend demonstrations. This is also the phase in which they have to be extraordinarily careful not to accept favours, which might be seen as influencing their judgment. Internationally cases exist where politicians accepted holiday trips or even outright payments for themselves or their party coffers.

- Practice varies as to how authority to sign the definitive contract is obtained, sometimes preceded by a letter of intent. In the Netherlands this depends on the money value. Contracts below Euro 5 millions are left to the service concerned. Up to Euro 25 millions the projects have to be included in the overall defence plan by the Chief of the Defence Staff in his role of »corporate planner « and communicated to parliament. For procurement orders between Euro 25 and 100 millions the requirement has to be approved by the parliamentary committee at the beginning of the procurement cycle, but further execution is mandated to the service concerned, unless the project has been qualified as »politically sensitive«. Projects of higher value need parliamentary approval before signature and decisions regarding their implementation can only be taken by the State Secretary (deputy minister) in charge of equipment. Contracts above Euro 250 millions require approval by the full cabinet before they are submitted to parliament. If the parliamentary committee does not give the green light, members can put the issue on the agenda of the plenary session of the Second Chamber for a debate and vote.

- The model sequence outlined above, or something similar, is practiced in only a few NATO countries. DCAF Occasional Paper No. 2 on »Democratic control of armed forces: the national and international parliamentary dimension « includes a comparative table on parliamentary authority, either in plenary or in committee. ${ }^{7}$ The record was not bad in terms of legislation, but less good on control of the executive. The Minister of Defence is obliged to provide information to the defence committee on procurement decisions above a certain amount in Germany (above $€ 25$ millions), the Netherlands (above $€ 5$ millions), Norway (above $€ 0.8$ millions), Poland and the UK. In all these countries except the UK he needs parliamentary consent to conclude the contract. Involvement of the committee in specifying the need for new equipment is provided for in Canada, the Czech Republic, France, Germany and the Netherlands;

7 See van Eekelen, Note 5. 
and in the comparison of offers and selection of a producer in the Czech Republic, the Netherlands and Norway. Only the Czech and Netherlands parliaments reported involvement in the assessment of compensation and offset arrangements.

All NATO countries have parliamentary committees on defence, but few have expert support. There is no lack of independent think-tanks, but rarely does parliament instigate research of its own, challenging the official views. In the USA the Congressional Research Service of the Library of Congress provides an impressive array of documentation and support, but does not have a separate defence section. The Congressional Budget Office traces the implementation of authorised expenditure. In the UK parliament has a large library with some 200 experts and an International Affairs and Defence Section. There is no specific research bureau for defence matters, but the Select Committee on Defence has its own staff, who often consult external expertise. The German Bundestag has its Wissenschaftlicher Dienst with three persons working on defence and security and links with independent institutes like the Stiftung Wissenschaft und Politik. The French National Assembly has a Service des Etudes et de la documentation with a staff of 36, and the defence committee a supporting staff of seven persons. Norway has a Council on Defence Research, which advises the government. The Swedish Riksdag has a research service with some 30 staff collecting public information. Parliament has the right to request research by government-subsidised institutions, but rarely does so. The Stockholm International Peace Research Institute produces an impressive yearbook, book-size studies and reports, but has an international agenda, like the International Institute of Strategic Studies in London.

\section{A new security agenda}

Without trying to be too academic it is worth noting that modern Western society has developed a new paradox, which has to do with the difference between value-based and interest-based international cooperation and the confusion between values and norms. Values come first and norms are derived from them. In Western organisation the sharing of sovereignty has become the norm, but risk-sharing is the value. The goal of peace has become more of a process and less of a product. The paradox lies in the fact that at the same time our societies have become averse to risk; a management ethos has taken the place of great ideals. The result is constant debate about every choice, compounded by the absence of precise criteria for maintaining levels of forces and the corresponding financial effort. Everything has become a matter of appreciation and everybody is in danger of losing track.

Under these circumstances parliamentarians should attempt to follow a comprehensive and consistent approach, following clearly established procedures for defence committee proceedings and plenary debates:

- First, governments should present, follow and update their security concepts and security policies. These should specify the defence needs in the strict sense of the word that is the preservation of independence and territorial integrity, and be accompanied by a threat assessment process.
- Second, the level of ambition for participation in international peace support operations should be determined, defining concrete contributions in terms of units and skills and readiness for deployment outside the country.

- Third, personnel and equipment levels should be geared to these ambitions, including training, logistic support and cooperative arrangements. The preferred option would be to form »force packages «, trained and ready for deployment as soon as a crisis erupts and the political decision to join the operation is taken.

- Fourth, in NATO and EU more attention should be paid to the acquisition plans of allies and partners. The NATO planning and review process (PARPS) provided for a comprehensive evaluation by the military authorities. The EU follows a voluntary bottom-up process, which so far lacks the top-down process of proposing adjustments to member countries. It is not good enough to identify shortfalls and hope that somebody will fill them. Evaluation by the European Defence Agency might fill the gap.

- Fifth, parliamentarians should make sure that governments apply the democratic processes of »reveal, explain and justify « also to the equipment sector. On the budgetary side, parliamentarians have to be convinced that there will be sufficient funding for the plans submitted to them, not only in the current year, but during the entire acquisition phase. Governments have a tendency to underestimate price escalation in long term projects, and to be more optimistic about future resources than in the current year. Germany and Romania have provided examples of procurement plans, which they could not afford. Statistically, estimates of total project costs have always been on the low side, and sometimes intentionally so. Cost overruns are frequent, delays occur, and flanking programmes are becoming more expensive than budgeted. As defence procurement involves long lead times, it is important to assess the impact on long-term capacity building to ascertain how new equipment will fit into a harmonious composition of the armed forces. The current emphasis on »jointness « makes this even more necessary. Equally, attention should be paid to the life cycle costs of the new systems, including maintenance, updates and the personnel needed to handle them.

Parliamentary control of defence matters rests with national parliaments. Nevertheless, the parliamentary assemblies of NATO and WEU have played an important role in providing an international dimension to the debate. Their reports are of a high quality and a useful source of information to parliamentarians, the media and the public at large. Debating them and working and voting on joint resolutions raise the level of awareness in a process which could best be described as »consensus building «. Returning home to their own parliaments members profit from the common appreciation (or differences) when they have to take the floor in the national debate. 